\title{
The Effect of Visual Merchandising, Sales Promotion and Positive Emotion of Consumers on Impulse Buying Behavior
}

\author{
Christina Catur Widayati Hapzi Ali Dudi Permana Muklis Riyadi \\ Universitas Mercu Buana Jakarta
}

\begin{abstract}
This study is to determine the effect of Visual Merchandising Effect, Sales Promotion and Positive Emotion on Impluse Buying Behavior. Data was collected through 155 respondents who visited the South Tangerang AEON Mall, a questionnaire-based data collection technique using a Likert scale. The method used in this research is nonprobability sampling and the data is processed with multiple linear regression equations by using the IBM SPSS Version 23 application to determine the magnitude of the percentage of the contribution of the influence of the Independent variable on the Dependent variable. The results showed that Visual Merchandising variables and Sales Promotion variables partially had a significant effect on Impluse buying variables while Positive Emotion variables did not partially influence the Impluse Buying variable. This research can be used as a recommendation for the company AEON Co.It as the parent company of AEON Mall as a recommendation to maintain and increase the number of visitors so that the company can continue to run and move forward.
\end{abstract}

Keywords: Visual Merchandising, Sales Promotion, Positive Emotion, Impluse Buying

DOI: $10.7176 / \mathrm{JMCR} / 60-02$

Publication date:September $30^{\text {th }} 2019$

\section{INTRODUCTION}

Along with the development of increasingly modern times and economic conditions also experienced growth. Where the company must be able to meet consumer demand which is increasingly becoming more diverse (Astry, 2010). The rapid flow of information caused by the development of globalization makes people now have a consumptive lifestyle. Increased consumer income also supports a consumptive lifestyle and causes consumer needs to increase. According to Kurniawan and Kunto (2013), the need to continuously increase causes the level of consumer spending to increase. Consumer behavior that often occurs at this time, especially when inside the mall is impulse buying. The product quality is a factor to support purchasing decisions. Atmosphere of competition and the increasing demand by consumers led many companies seeking to realize his desire to produce a quality product quality that can compete in the market. A company should be able to perform a variety of efforts and strategy to master the market position, and strive to improve and develop the quality or the quality of the product. (Brata, Husani, \& Ali, H. (2017).

Research states that nine out of ten buyers claim that they made purchases outside their shopping list. $66 \%$ of them admitted that the reason for the purchase was due to a sale or promotion, $30 \%$ because they got a coupon, and $23 \%$ due-to the desire to spoil them selves (www.newmediaandmarketing.com). Because this phenomenon occurs quite often, then for a company "impulse buying" becomes something that can create positive results expected by all companies, namely increased sales. Therefore, the company must know the consumers so that they eventually do impulse buying. Nearly half of the total sales are the result of impulse buying behavior carried out by consumers. Companies must be able to maintain impulse purchases in

the current period which causes a reduction in the number of products spent by consumers. Buyers try to save their purchases and reduce impulse purchases. Therefore, it is important for companies to obtain information in determining the competitive strategy that must be carried out on impulse buying behavior so that the company can survive and excel in the competition. Consumers now spend a lot of time on recreation or just hanging out with their friends and family to go to the mall. When in the mall, consumers who originally planned to just let go of fatigue turned into unplanned shopping activities. The behavior of impulse buying is often found in malls.

Visual merchandising is a technique in presenting visual display of merchandise that attracts attention and is shown-to potential customers (Jain, et al., 2012). Good products and services will be more attractive and increase the desire of consumers to visit the store in question. This affects the desire of consumers to buy products without being planned in advance because they see interesting shops. Sales promotions made by companies can attract new consumers, influence customers to try new products, encourage consumers and customers to buy more, attack competitors' promotional activities, and increase impulse buying or buying not planned in advance (Tjiptono, 2008). The goal of sales promotion is to increase sales volume by increasing activity and attractive appearance, so as to create a sense of interest and a pleasant shopping atmosphere for consumers. The sales promotion strategy must be integrated and comprehensive so that a message can be conveyed comprehensively and consistently.

The positive emotions of consumers are defined as moods that influence and determine the intensity of 
consumer decision making (Watson, et al., 2009). Visitors who have subscribed to a store for reasons of liking or being comfortable with the environment in the store will unexpectedly spend more money as a result of an atmosphere that encourages a positive mood. Consumer positive emotions perceived by consumers will encourage consumers to acquire a product immediately without planning ahead of it and vice versa negative emotions can encourage consumers not to make impulse purchases (Premananto, 2007). Impulse to buy is hedonically complex and will stimulate emotional conflict. Impulsive purchases also tend to be done by ignoring consideration of the consequences (Christina Whidya, 2010). Unplanned buying behavior is a buying behavior that is done in a store, where the purchase is different from what is planned by the consumer when they enter the store (Utami, 2010). Impulsive buying is the tendency of consumers to making purchases spontaneously, not reflected, rushed, and driven by emotional psychological aspects of a product and tempted by persuasion from marketers (Hirschman and Stern in Sumarwan 2011).

The progress of South Tangerang City as a trade and service area puts the people in the South Tangerang City area into a very consumptive (Deslatama, 2016). The consumptive community in South Tangerang makes entrepreneurs interested in building a shopping center in South Tangerang. Proven from 30 shopping centers in Banten, 18 of them being in Tangerang. The concentration of large shopping centers in the Tangerang area is certainly inseparable from the population of 4 million people. On the other hand, a growing number of upper middle-class people with high purchasing power in the region. According to the Chairman of the APPBI Banten, Heru Nasution, the number will increase as the current trend is developing at this time. This trend is not only about shopping, but also meets the needs of entertainment, relaxation, culinary, meeting, and also lifestyle (Alexsander, 2014).

One of the centers in South Tangerang is AEON Mall BSD City, which is one of the first modern retail shopping centers in Japan. AEON is one of the biggest and most popular shopping centers. The end of the AEON Mall BSD City is always booming, on weekends, the atmosphere is sometimes like a market. Noisy and solid. Especially in certain places such as cinemas, food courts or restaurants to prayer rooms. The newest shopping center in South Tangerang is indeed a prima donna. In fact, when it was first opened the location of the AEON Mall BSD City was isolated. But it is strategically located in the middle of the city of BSD, thus enabling people to come to AEON Mall BSD City. Serpong area (BSD) which was chosen as the first footing of AEON Mall was considered quite potential. While there are many shopping centers around there like Living Word, Mall Alam Sutra, or Summarecon Mall Serpong, AEON Mall optimism can captivate people around even outside the region. According to Andrian Pranata as the Operations General Manager of PT AMSL Indonesia, the uniqueness and location not far from the toll road are some of the advantages of the mall (Anjani, 2015).

One of the achievements AEON Mall BSD City is awarded the best Mall in South Tangerang area beat Mall-Mall in the same region as Living Word, Mall Alam Sutra, or Summarecon Mall Serpong. AEON Mall BSD City Mall concept is the first Japanese in Indonesia, which was awarded Top Property Award (TPA) in 2016. This award bestowed upon developers, banks, brokers, products and brands that have a peak performance in the world of the property. This is achieved because the success of AEON Mall BSD City in attracting visitors, the initial target perfomance one-year target of 12 million visitors within one year from the start to the grand opening, but the target was successfully achieved in less than 1 year and continues to increase every yea (m.republika.co.id).

\section{LITERATURE REVIEW}

\section{Visual Merchandising}

Visual Merchandising is a salesperson who does not speak but can be sure to deliver sales messages through visual stimuli (Jain, 2013). Visual merchandising is a technique for displaying merchandise that is eye-catching and shown to potential customers (Jain, et al., 2012). Simple visual merchandising is the appearance of a product or merchandise well and interesting in terms of color, supporting accessories with the right long tools (Sugiarta, 2012).

According to Mathew visual merchandising is the creation of a visual display and arrangement of various merchandise in the store to improve the layout and presentation of stores to increase store traffic and sales (Mathew, 2008). The visual merchandising display process is often referred to as "silent sellers by providing information to consumers through visual media and also with suggestive sales. Merchandising is part of retail max, where a company conducts the procurement of products that are in accordance with the business in which the store is going to be provided in the amount, time and price that is appropriate to reach the target store or retail company (Hendri, 2005).

This is supported by research conducted by Mehta \& Chugan, which suggests that visual merchandising is the only technique for creating euphoria in the clothing industry through presentations that are displayed in stores (Metha and Chugan, 2013). Visual merchandising includes both store exterior and interior. The store exterior includes window display, façade and retail premises. Window display is a medium which creates first impression in customer's mind to enter the store (Mehta \& Chugan, 2013). 
Visual merchandising function in clothing retailing (Bell \& Ternus, 2012): (1) Support sales; (2) Support retail strategies; (3) Communication with customers; (4) Helps in communicating fashion retail brand image; (5) Supporting trends in retail

Visual merchandise is a form of advertising made from 3-dimensional forms and occupying space, but taking into account the beauty and good way of communicating and producing it, it means taking into account the aspects that are not achieved in graphic design, interior design, and visual communication. How to make visitors not only see but approach, enter the store, enjoy the atmosphere and finally decide to buy at a short time not waiting for tomorrow or another day's opportunity. (Arifah, 2017) There are several important dimensions in visual merchandising (Mehta \& Chugan, 2013), namely:

1) Window display, a media that creates the first impression on the customer's mind to enter a store (Mehta \& Chugan, 2013)

2) In-store from / mannequin display, a tool to show or explain the current and identical fashion of a store's brand to be a tool to showcase or explain current fashion trends and a store's brand identity (Bell \& Ternus, 2012)

3) Floor merchandising is the arrangement of equipment that supports the implementation of retail business in creating space for customers in the store (Ebster \& Garaus, 2011)

4) Promotional signage is a tool or media that is used to convey messages to customers regarding promotions or events that are taking place in a store (Pegler, 2012).

\section{Sales Promotion}

Sales promotion is a direct stimulus to consumers to make purchases (J. Paul Peter and Jerry C. Olson 2014). Sales promotion is oriented to changing consumers' buying behavior immediately. Sales promotion is a store promotion program in order to encourage sales or to increase sales. In general, sales promotions run by stores have several objectives, including: maintaining customer interest to keep shopping at the store, introducing a new product or new outlet, competing with competitors' programs that hold sales promotion programs, luring potential consumers who have never shop at the store, utilizing the season / trend or the tendency of shopping behavior patterns at the store (eg during the preparatory period for the beginning of the new school year) or to stimulate customer interest in switching brands (Christina Whidya, 2010).

The purpose of sales promotion is to increase sales volume by increasing activity and attractive appearance, so as to create a sense of interest and a pleasant shopping atmosphere for consumers (Anggun, 2017).

The purpose of using sales promotions according to (Kotler and Armstrong 2004) is: (a) Attract new buyers; (b) Giving gifts or awards to old customers or customers; (c) Increase the purchasing power of old customers; (d) Avoid consumers from running to other brands; (e) Popularize brands/increase loyalty; (f) Increase short-term sales volume and expand long-term market share

Sales promotions made by companies can attract new consumers, influence customers to try new products, encourage consumers and customers to buy more, attack competitors' promotional activities, and increase impulse buying or buying not planned in advance (Tjiptono, 2008).

There are three main statements of sales promotion (Tjiptono: 2008). Which makes the dimensions in this study:

1) Consumer Promotion (consumer promotions), including product coupons, free samples, premium, gifts, sweepstakes and so on

2) Trade promotion, including cash discounts, merchandise (merchandise), equipment assistance, specialty advertising, or other incentives for retailers or wholesalers

3) Salesforce promotions, such as sales contests

\section{Positive emotion of consumers}

A person can place certain emotions, such as feelings of joy, anger, joy, and sadness. For example, if a person feels happy and encouraged, then he is very happy and active enough, then that person may be experiencing emotions of happiness. Basically, the psychological approach proposes his views on human behavior that human behavior is influenced by the environment (Brian, 2014). Purchasing motives related to feelings are emotional motives. If when shopping consumers feel happy, comfortable, safe and passionate, then the emotions that exist in the consumer are positive emotions of consumers (Dharmmesta, 2014: 69). When shopping consumers feel happy, comfortable, safe and passionate, the emotions that exist in the consumer are positive emotions of consumers (Dwi, 2016).

Positive consumer emotion is a tendency of a person's affective nature, which appears before the formation of mood, and is the result of a reaction in an environment that supports interest in the product or an attractive sales promotion will influence consumer purchasing decisions (Rachmawati, 2009). Consumer positive emotions can be seen through positive feelings such as happy, loving, liking, enjoying, satisfied and alert (Peter and Olson, 2005). Emotions which include feelings and moods (mood) are important factors in making decisions by 
consumers (Park, Kim, and Forney, 2006). Peter and Olson clarify emotions into two dimensions, namely positive and negative (Peter and Olson, 2005). Consumer's positive emotions perceived by consumers will encourage consumers to acquire a product immediately without planning ahead of it and vice versa negative emotions can encourage consumers not to make impulse purchases (Premananto, 2007). According to Laros and Steenkamp (2005), "Emotion is reaction assessment (positive or negative) of a complex nervous system of a person towards external or internal stimuli and often conceptualized as a general dimension, such as the positive and negative influences". This means that emotions are an assessment reaction (positive or negative) of a person's nervous system to external or internal stimuli and are often conceptualized as a general dimension, such as that which influences positively and negatively (Laros, Steenkamp and Brian, 2014). The visitors who have subscribed to a store for reasons of liking or comfortable with the environment in the store will unexpectedly spend money that encourages the emergence of a positive mood (Park, Kim, and Forney, 2006: 442). Thus, the greater the positive emotions of customers, the greater the desire to buy impulsively (Varhagen and Dolen, 2011).

There is an important dimension in the positive emotions of consumers (Mehrabian, Russel and Jovita, 2017), namely:

1) Pleasure. Pleasure refers to the level at which individuals feel good, full of joy, happy with regard to the situation.

2) Arousal. Arousal is a situation where a person feels alert, excited, or active.

3) Dominance. Dominance is a condition that refers to the extent to which a customer feels in control or is free to do something in a store.

\section{Impulse Buying}

Purchasing impulse buying occurs when consumers suddenly experience a strong and strong desire to buy something immediately (Utami, 2010). Unplanned purchases (impulsive products) are mostly found in items that are desired to be purchased, and most of the items are not needed by consumers. Impulsive purchases or unplanned purchases are another forms of consumer buying patterns. In accordance with the term, the purchase is not specifically planned. "Impulsive purchases" occur when consumers suddenly experience a strong and strong desire to buy something as they like. The impulse to buy is hedonically complex and will stimulate emotional conflict. Impulsive purchases also tend to be done by ignoring consideration of the consequences (Christina Whidya, 2010). Unplanned purchases are buying behaviors where consumers do not consider buying, or considering buying but have not decided what product to buy (Mawardi 2011). According to Hirschman, the impulsive purchase is the tendency of consumers to make purchases spontaneously, not flexed, rushed, and driven by emotional psychological aspects of a product and tempted by persuasion from marketers (Mawardi, 2011). Factors related to purchasing are not planned (Faber in Mawardi 2011). Covers:

1) Psychological factors such as self-esteem, depression, anxiety, and perfectionism

2) Biological factors are reflected in the effects of liquor therapy and neurotransmission, personal, and family history on consumptive purchases related to irregularities

3) Cultural factors such as gender roles, children's early experiences, and changes in social norms such as feelings of isolation

There are two factors in impulse buying, namely internal and external factors. Internal factors can be in the form of consumer hedonism that arises when shopping and the mood of consumers who are happy when in the store, this study referred to as positive consumer emotions. While external factors can be in the form of sales promotions, visual merchandising displayed in the store (Yanti and Japarianto, 2014).

There are four types of impulsive buying which are the dimensions of impulse buying (Christina Whidya, 2010), namely:

1) Pure impulse (pure impulse), this understanding refers to the act of buying something for interesting reasons, usually when a purchase occurs because of brand loyalty or purchasing behavior that can be done.

2) Impulse reminders (reminder impulse), when consumers buy based on this type of impulse, this is because the unit is usually purchased as well, but does not occur to be anticipated or recorded in the shopping list.

3) Impulse suggestion (suggestion impulse), a product that consumers encounter for the first time will stimulate the desire to try it.

4) Planned impulse, the planning aspect of this behavior shows the consumer's response to some special incentives to buy an unanticipated unit. These impulses are usually stimulated by coupon sales announcements, coupon discounts, or other tempting offers.

\section{HYPOTHESIS}

The relationship between visual merchandising to impulse buying

Display plays an important role in capturing the hearts of consumers, with an attractive appearance that 
consumers are expected to come to see, be interested and finally buy. Visual Merchandising is a salesperson who does not speak but can be sure to greet sales messages through visual stimuli according to (Jain, 2013).

Visual merchandising is the creator of the beautiful imagination and the emotional language of the product from the store and Brand, then makes it a real object that is organized and speaks, to please the visitors. Visual Merchandising can make visitors not only see but approach to enter the store, enjoy the atmosphere and finally decide to buy at that time not to wait for tomorrow or another day's opportunity. Visual Merchandising influences Impulse buying supported by research conducted by Ni Made Dewi Desyantari Putri (2017), who stated that Visual merchandising has a significant influence on Impulse buying, and Research conducted by Devi Yanthi and Edwin Japarianto (2014) also concluded that Visual Merchandising has an influence on Impulse Buying.

$$
\mathbf{H}_{1} \text { : Visual merchandising affects impulse buying }
$$

\section{The relationship between sales promotion to impulse buying}

Sales promotion is a direct stimulus to consumers to make purchases (J. Paul Peter and Jerry C. Olson 2014: 205). Sales promotion is marketing activities in addition to personal sales, behavior, and publicity, which encourage consumer purchases and the effectiveness of dealers. Sales promotions usually offer incentives to consumers and resellers to encourage short-term demand for a product.

Promotion is not only a tool to introduce products, product sales, and communication tools between companies and consumers but also as a tool to influence consumers in purchasing activities according to their wishes. Sales promotions made by companies can attract new consumers, influence customers to try new products, encourage consumers and customers to buy more, attack competitors' promotional activities, and increase impulse buying or purchases not planned in advance (Tjiptono, 2008: 229).

Research conducted by Putu Bagus Wichatakani (2016) suggests that promotion has a positive and significant effect on Impulse Buying, and this is supported by research conducted by Anggun Suci Kiswaran and Suharyono (2017), concluding that Sales Promotion Variables have a significant effect on Impulse Buying.

$\mathbf{H}_{2}$ : Sales promotion affects impulse buying

\section{Relationship between consumer positive emotions to impulse buying}

A person can place certain emotions, such as feelings of joy, anger, joy, and sadness. For example, if a person feels very unpleasant and motivated, then he is very happy and active enough, then that person may be experiencing emotions of happiness. Positive emotions of consumers are defined as moods that influence and determine the intensity of decision making (Watson and Tellegen in Tirmizi, et al, 2009). The visitors who have subscribed to a store for reasons of liking or comfortable with the environment in the store will unexpectedly spend money that encourages the emergence of a positive mood (Park, Kim, and Forney, 2006).

Thus, the greater the positive emotions of customers, the greater the desire to buy impulsively (Varhagen and Dolen, 2011). Research conducted by Putu Vera Naentiana and Putu Yudi Setiawan suggested that positive consumer emotions variable had a positive and significant effect on Impulse Buying and Research from Dwi Eni Setiyorino (2016), also concluded that positive consumer emotions had a positive effect on Impulse buying. This is also supported by research conducted by Putra (2010), that positive consumer emotions have a positive and significant effect on impulse buying.

H3: Positive emotions of consumers affect impulse buying

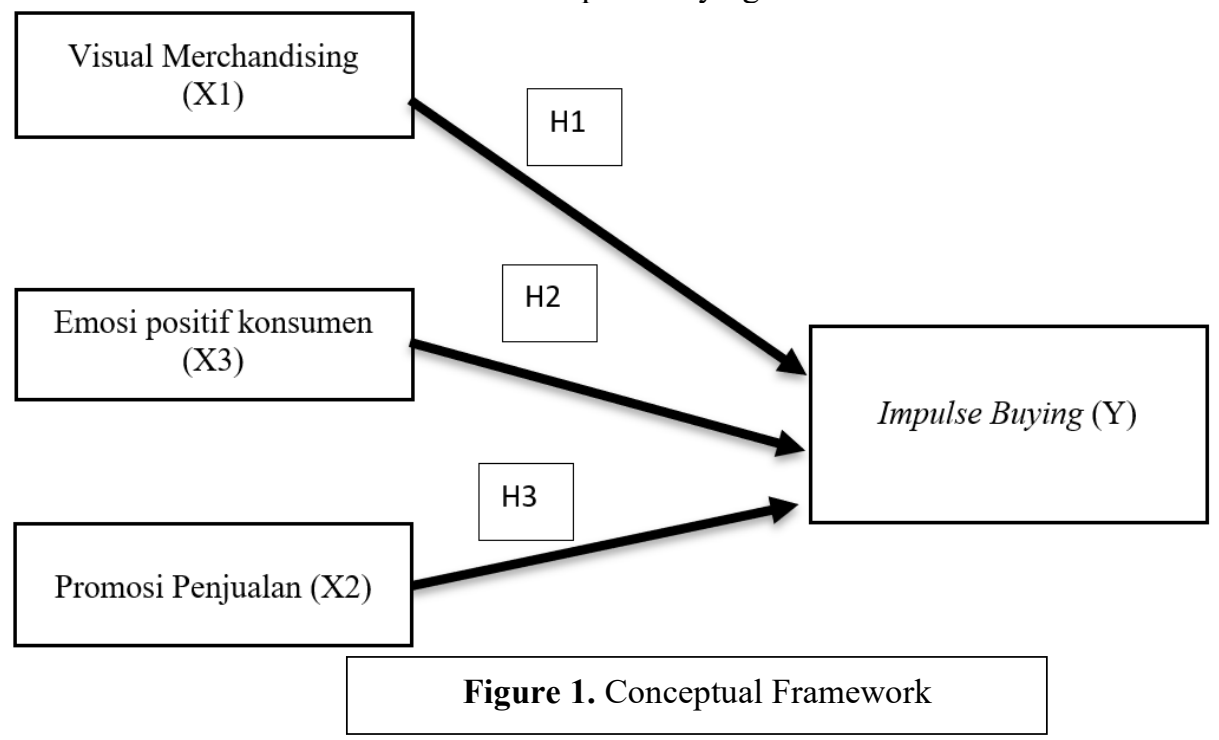




\section{METHODOLOGY}

A researcher will always relate to the research variable because this variable will reveal the research. Variables are anything in the form of what is determined by the researcher to be studied so that information is obtained about it (Sugiyono, 2013). The population is all subjects such as people, companies, and events or things that become research centers. The population in this study were visitors to AEON Mall BSD City, South Tangerang. The sample is part of the number and characteristics possessed by the population (Sugiyono, 2014). Characteristics of respondents needed to answer the questionnaire provided were respondents who were consumers who had visited AEON Mall BSD City, South Tangerang.

Based on the theory of Heir where the sample recommendations are taken in the study, at least 140, the researcher will spread the questionnaire and take a sample of 140 people to represent the existing population (Heir et al, 2008). In this study, researchers used nonprobability sampling method, according to (Sugiyono, 2014) nonprobability sampling is a technique that does not provide equal opportunities for each element or member of the population to be selected as a sample. In this study, researchers used purposive sampling. (Sugiyono, 2014) states that purposive sampling is a sampling technique with certain considerations. The criteria for being a respondent in this study were respondents who had visited at AEON Mall BSD City, South Tangerang.

The ideal and representative sampling size depends on the number of indicators multiplied by 5-20 (Hair, 2010). In this study using 28 indicators. The number of samples in this study is: Sample = number of indicators $x$ $5=31 \times 5,155$ Respondents

\section{DATA ANALYSIS}

AEON Co.lt is the parent company of AEON Mall which was founded in September 1926 as a retail company (General Merchandising Store / GMS). In February 2012, AEON Group operated hundreds of General Merchandising Stores, Discount Stores, Home Centers, and so on. AEON Group also operates thousands of specialty shops, pharmacies, convenience stores, and service businesses, said AEON having its origins in Latin which means "eternity". AEON is a company group that makes "contributions to customers" as a lasting mission and is a group of companies that perpetuate themselves to be customer oriented. AEON AEON Group which has the target to become the number one Super-Regional retail company in Asia has been operating in 12 countries: Japan, China, Hong Kong, South Korea, Taiwan, Philippines, India, Vietnam, Cambodia, Thailand, Malaysia, and Indonesia. AEON Mall operates more than 200 malls. In Japan, from all existing malls, 2/3 of them are operated by AEON Mall. In Indonesia, AEON Mall runs its business through PT AMSL Indonesia. AEON Mall BSD City has the most food court facilities and restaurants in the BSD City area with a total of 140 shops. The modern ground floor is divided into 2 concepts, namely Cafe Street and Food Culture with various restaurants and focus on Japanese food such as Uchioshokudo, Kaihomaru, Gyu Kaku Yakiniku, and so on.

\section{Partial T-test}

The statistical test $t$ basically shows how far the influence of an independent variable individually in explaining the variation of the dependent variable (Ghozali, 2011). In the $t$-test, the calculated $t$ value will be compared with the value of $t$ table.

Tabel 1. Statistical T-Test Result

\begin{tabular}{|c|c|c|c|c|c|c|}
\hline & \multirow[b]{2}{*}{ Model } & \multicolumn{2}{|c|}{ Unstandardized Coefficients } & \multirow{2}{*}{$\begin{array}{c}\text { Standardized } \\
\text { Coefficients }\end{array}$} & \multirow[b]{2}{*}{$t$} & \multirow[b]{2}{*}{ Sig. } \\
\hline & & $B$ & Std. Error & & & \\
\hline \multirow[t]{4}{*}{1} & (Constant) &,- 852 &, 854 & &,- 998 & ,320 \\
\hline & Visual Merchandising &, 647 & 015 & ,902 & 42,151 & 000 \\
\hline & Sales Promotion & 145 & 027 & 116 & 5,413 & 000 \\
\hline & $\begin{array}{l}\text { Positive Emotion of } \\
\text { Consumers }\end{array}$ & 021 & 020 &, 018 & 1,038 & ,301 \\
\hline
\end{tabular}

a. Dependent Variable: Impulse Buying

Based on Table 1 it can be seen that:

a) Visual Merchandising $\left(\mathrm{X}_{1}\right)$ against Impulse Buying $(\mathrm{Y})$

Based on table 1 in the Coefficient variable Visual Merchandising variable is 0.647 and the value of $t$ count 42.151 is greater than $t$-table 1.655 or $t$ count $>t$ table. Visual Merchandising sig value 0,000 is smaller than the probability value 0,05 or $0,000<0,05$, so it can be concluded that the Visual Merchandising $\left(\mathrm{X}_{1}\right)$ variable has a positive and significant effect on Impulse Buying $(\mathrm{Y})$.

b) Sales Promotion ( $\mathrm{x}_{2}$ ) against Impulse Buying (Y)

Based on table 4.22 in column Coefficient Sales Promotion variable is 0.145 and t count value is 5.413 greater than $\mathrm{t}$ table 1.655 or $\mathrm{t}$ count $>\mathrm{t}$ table. The value of Sales Promotion sig 0,000 is smaller than the probability value of 0.05 or $0,000<0.05$, so it can be concluded that the Sales Promotion Variable (X2) has a positive and significant effect on Impulse Buying $(\mathrm{Y})$. 
c) Positive consumer emotions (X3) towards Impulse Buying (Y)

Based on table 4.22 in the Coefficient column variable positive consumer emotions are 0.021 and t count value is 1.038 less than $t$ table 1.655 or $t$ count $<t$ table. Sig value of positive emotion of consumer 0.301 is greater than the probability value of 0.05 or $0.301>0.05$, so it can be concluded that the positive variable emotion of consumers (X3) does not affect Impulse Buying (Y).

\section{Partial F-test}

Tabel 2. Statistical F-Test Result

\begin{tabular}{llrrrrr}
\hline Model & & Sum of Squares & $d f$ & Mean Square & $F$ & Sig. \\
\hline 1 & Regression & 4158.587 & 3 & 1386.196 & 1118.172 & $.000^{\mathrm{a}}$ \\
& Residual & 190.913 & 154 & 1.240 & & \\
& Total & 4349.500 & 157 & & & \\
\hline
\end{tabular}

a. Predictors: (Constant), Positive consumer emotions, Visual Merchandising, Sales Promotion

b. Dependent Variable: Impulse Buying

Based on Table 2, it can be seen that the F-value counts 1118,172 with a probability of sig 0,000 , that means the probability value $<0,05$, while the results obtained from F-table is 2,66 which means F-count $>$ F-table $(1118,172>2,66)$, so that the regression model can be used to predict Impulse Buying behavior or it can be concluded that Visual Merchandising, Sales Promotion and positive Emotion of consumers together influence the Impulse Buying Behavior, or the model is right.

\section{Determination Coefficient Test}

Tabel 3. Determination Coefficient of $\mathrm{R}^{2}$

Model Summary ${ }^{\mathbf{b}}$

\begin{tabular}{rcccc}
\hline Model & $R$ & $R$ Square & Adjusted $R$ Square & Std. Error of the Estimate \\
\hline 1 &, $978^{\mathrm{a}}$ &, 956 &, 955 & 1,11342 \\
\hline
\end{tabular}

a. Predictors: (Constant), Positive consumer emotions, Visual Merchandising, Sales Promotion b. Dependent Variable: Impulse Buying

Based on Table 3 can be seen the value of Adjusted R Square is 0.955, this means 95.5\% variation of the dependent variable Impulse Buying can be explained by the three variations of the independent variables namely Visual Merchandising, Sales Promotion and positive emotions of consumers. While the remaining $0.05 \%$ can be explained by other variables not included in this research model. For example, variable Store Environment, Personality Trait, Conformity, Personal Selling etc.

\section{DISCUSSION AND FINDINGS}

a) Visual Merchandising Effect on Impulse Buying

Based on the results of the calculation of the t-test shows the results of the $t$ count value of 42.151 and a significance value of 0.000 . The value of $t$ count is greater than the value of table 1.655 and the significance value is less than the value of 0.05 , this indicates that Visual Merchandising has a positive effect on Impulse Buying. The management of AEON Mall BSD City and tenants are expected to maintain the Visual Merchandising Display that has been done and added by always updating their innovations such as setting specific themes, designing a more attractive window display, enriching the knowledge of the sales team and updating items what is displayed so that visitors are encouraged to enter the store, with an attractive shop appearance, is expected to encourage Impulse Buying Behavior.

b) Effect of Sales Promotion on Impulse Buying

Based on the results of the calculation of the t-test shows the results of the $t$ count value of 5.413 and a significance value of 0.000 . The value of $t$ count is greater than the value of $t$ table 1.655 and the significance value is less than the value of 0.05 , it indicates that Sales Promotion has a positive effect on Impulse Buying. The management of AEON Mall BSD City and tenants (Tenants) are expected to maintain sales promotions that have been carried out and carried out several extras such as conducting in-store sales promotion activities which are clearly informed and communicated to visitors, for example through catalogs containing information about products what is currently on promotion. The catalog can be placed or displayed near the shop entrance or distributed in the shop. In addition optimization of salesperson or SPG roles is also needed to persuade and provide information about products and promotions orally and directly to visitors. The presence of a salesperson is expected to influence consumers to carry out Impulse Buying behavior

c) Effect of positive consumer emotions on Impulse Buying

Based on the results of the calculation of the t-test shows the results of the $t$ count value of 1.038 and the significance value of 0.301 . The value of $t$ count is smaller than the value of table 1.655 and the significance 
value is less than the value of 0.05 , this indicates that the positive emotions of consumers do not affect Impulse Buying. This shows that the positive emotion of consumer consumers has not been managed well by the Management of AEON Mall BSD City and tenants (visitors), visitors feel they have not fulfilled their pessimistic aspect when in AEON Mall BSD City, therefore the thing to do is try to understand consumer needs by involving emotions such as making it easier for consumers to convey their complaints, playing music in accordance with trends, paying attention to the cleanliness of toilets, keeping the air conditioner cool and utilizing aromas that are known to improve the mood of visitors, so that visitors feel happy and encourage to do Impulse behavior Buying.

\section{CONCLUSION AND SUGGESTIONS}

Conclusion. Based on the data that has been collected and has done the problem testing phase using multiple linear regression models as described in the previous chapter, the following conclusions can be drawn: (1) Visual Merchandising has a positive and significant effect on Impulse Buying behavior at AEON Mall BSD City; (2) Sales Promotion has a positive and significant effect on Impulse Buying behavior at AEON Mall BSD City; (3) Positive emotions of consumers do not affect Impulse Buying behavior at AEON Mall BSD City. This is because positive consumer emotions are not the dominant reason for Impulse Buying Behavior.

\section{Suggestions}

1) To improve Impulse Buying purchasing behavior at AEON Mall BSD City to maintain and enhance more comfort at AEON Mall BSD City by enriching the design through the use of interior elements, coloring, lighting, air circulation and the aroma that is expected to create feelings certain in the minds of consumers and can lead to Impulse Buying Behavior.

2) To improve the buying behavior of Impulse Buying at AEON Mall BSD City, it is suggested to place the promo that is given more easily, for example, enlarge the appearance of promotional media, create creatively according to the trend that the sedan develops, put promotional media that easily looks like near the visitor's entrance, near the cashier and more often make other advertisements or promotions by means of print, electronic or internet media.

3) To improve Impulse Buying purchasing behavior at AEON Mall BSD City, management is advised to pay more attention to customers' emotions, in the survey that has been given, visitors give the lowest rating on the statement about happiness at AEON Mall BSD City, it can illustrate that visitors not happy when I was at AEON Mall BSD City so the management needs to add things that increase the positive emotions of customers such as playing music according to the current trend, improving good and friendly service to customers so that shopping will be more enjoyable, by trying to meet customer needs, and keep smiling friendly and not letting customers wait too long.

This research is expected to be the basis for future research. For those who want to research more about Impulse Buying behavior, can add other variables such as Store Environment, Personality Trait, Conformity, and Personal Selling as variables that can increase sales that can affect Impulse Buying Behavior. In addition, it is expected that researchers will then be able to expand the range of research areas such as modern shopping centers in other areas so that more optimal research can be found.

\section{REFERENCES}

Bell, J., \& Ternus, K. (2012). "Silent Selling 4rd Ed". New York: Fairchild Publications.

Brata, B. H., Husani, S., \& Ali, Hapzi. (2017). The Influence of Quality Products, Price, Promotion, and Location to Product Purchase Decision on Nitchi At PT. Jaya Swarasa Agung in Central Jakarta. Saudi Journal of Business and Management Studies, 2(4), 357-374.

Dewi, Larassanti. (2016). "The Influence of Lifestyle, Store Atmosphere, and Hedonic Shopping Value on the Impulsive Purchasing Behavior of AEON Department Store BSD City Customers". Thesis, Syarif Hidayatullah State Islamic University Jakarta, Jakarta.

Graceful. S. D. P. (2017). "The Effect of Hedonic Shopping Motives and Sales Promotion on Impulse Buying on Matahari Consumers Departing Malang Town Square Store". Journal of Business Administration (JAB). UB Faculty of Administrative Sciences Malang. 47 (2), 146-151.

Hidayah, Astry. (2010). "The Influence of In-Store Sales Promotion on Impulse Buying Decisions on Hyperak Lebus Carrefour Customers". Thesis, Bogor Agricultural Institution, Bogor.

I Komang N, K., (2016). "The Effect of Visual Merchandising on Impulse Buying Behavior on Retail Fasion (Case Study on Retail 3 Second, Kota Malang)". Journal of Marketing Management. Malang Faculty of Economics and Business, Malang, 9-10.

Jain, D. R. (2013). "Effect of Visual Merchandising of Apparel on Impulse Buying Behavior of Women". Indian Jornal of Applied Research, 3 (12), 310-312.

Jain, V., Sharman, A., \& Narwal, P. (2012). "Impact of Visual Merchandising on Consumer Behavior for 
Women 'Apparel". International Journal of Research in Management, 5 (2), 106-117.

Japriant, Edwin \& Sugiharto, Sugiyono., (2011). "The Effect of Shopping Life Style and Fashion Involvement on Impulse Buying Behavior of High Income Surabaya People". Journal of Marketing Management, Petra Christian University, 6, (1), 32-41.

Jovita G. S. (2017). "Effect of Visual Mercandising on Impulse Buying through Positive Emotion on Zara Surabaya". Junal Marketing Management, 11 (1), 19-21.

Khoirunnisa, Arifah. (2017). "The Effect of Visual Merchandising on Impulse Buying Behavior in Solo Paragon Mall". Thesis, Surakarta State Islamic Institute, Surakarta. Kurniawan, D., Yohanes Sondang Kunto. (2013). "The Effect of Promotion and Store Atmosphere on Impulse Buying Debgab Shopping Emotion as an Intervening Variable Case Study at Matahari Department Store Supermall Branch Surabaya". Petra Management Journal, 1 (2), 1-8.

Kosyou, Hidayat \& abdillah. (2014), "The Effect of Hedonic Motives on Lifestyle Shopping and Impulse Buying (Survey at stradivus outlet customers at Galaxy Mall Surabaya)". Journal of Business Administration, 14 (2), $1-7$.

Kotler, P., Gary Armstrong. (2008). Principles of Marketing, Volume 2. Twelfth Edition. Jakarta: Erlangga Publisher.

Kotler, P., Kevin Lane Keller. (2009). Marketing Management, Volume 2. Thirteenth Edition". Jakarta: Erlangga Publisher.

Mathew, R. (2008). Apparel Merchandising. New Delhi: Book Enclave

M. C, Cant and Mrs. Y, Hefer (2012), "Visual Merchandising Displays: Wasted Effort or Strategic Move? The Dilemma Faced By Apparel Retail Stores ", The Journal of Applied Business Research, 28 (6), 1489-1496.

Mehta, N. P. \& Chugan, P.K. (2013). "The Impact of Visual Merchandising on Impulse Buying Behavior of Consumers: A Case from Central Mall of Ahmedabad India". Universal Journal of Management. 1 (2), 7682 .

Ni, Made, Dwi. D P., (2017). "The Effect of Hedonic Motive \& Visual Merchandising on Shopping Lifestyle \& Impulse Buying at Matahari Department Store Lombok Epicentrum". Megister Management Journal. University of Mataram, 2-8.

Park, E. J., Kim, E. Y., \& Forney, J. C. (2006). "A Structural Model of Fashion Oriented Impulse Buying Behavior". Journal of Fashion Marketing and Management, 10 (4), 433-446.

Peter, J. P., \& Olson, J. C. (2005). Consumer Behavior And Marketing Strategy, 7th Ed. New York: McGrawHill.

Permana, Brian. (2014), "Analysis of the Influence of Promotions, Positive Emotions of Consumers and Store Environment on Impuse Buying Behavior Case Studies on Tong Hien Supermarkets in Semarang City". Thesis, Diponegoro University Semarang. Semarang.

Premananto, Gancar Candra. (2007). "Progress of Decision Making of Impulse Removal with Environmental Psychology Approach and Chain of Causality". Anticipation Journal, 10 (1), 172-184.

Putu Vera. N., \& Putu Yudi. S., (2014). "The Role of Postive Emotion in Mediating the Effect of Hedonic Shopping Value on Impulse Buying at Mall Bali Galeria". Journal of Management. Faculty of Economics and Business, University of Udaya Bali, 2318-327.

Rachmawati, Veronica. (2009). "The relationship between Hedonic Shopping Value, Positive Emotion, and Impulse Buying Behavior in Retail Consumers". Economic Magazine. XIX (2), 192-209.

Rangkuti, Freddy. (2013). SWOT Analysis: Techniques for Dissecting Business Cases How to Calculate Weight, Rating, and OCAI. Publisher PT. Gramedia Main Library. Jakarta.

Sugiyono, (2010). Quantitative and Qualitative Research Methods for $R \& D$. Alfabet, Bandung.

Simatupang. D. S. (2007). "Let's Get the Buyer Direct". MARKETING Magazine. (8) 31-32.

Sullivan, Gia j, Dr. slice B. Mauss. (2008). "Got To Have It: The Effects of Stress and Automatic Regulation of Stress on Impulse Buying". Journal of Personality and Social Psychology, p. 1-49.

Sumarwan, Ujang. (2011). Consumer behavior. Bogor. Ghalia Indonesia.

Tjiptono, F. (2008). Marketing strategy. Third Edition. Yogyakarta: ANDI Publisher.

Utami, Christina Whidya. (2008). Retail Marketing Strategy. Jakarta: Index.

Utami, Christina Whidya. (2010). Retail Management: Strategies and Implementation of Modern Retail Business Operations in Indonesia. Jakarta: Salemba Empat.

Yanti D. \& Japarianto E. (2014). "Analysis of Hedonic Shopping Tendency and Visual Merchandising Effect on Implanting Buying with Positive Emotion as Intervening Variables in the Sunroom Department Store Department of Tunjungan Plaza Surabaya". Journal of Marketing Management. 2 (2), 2-4. 